\title{
Commentary to Wetter et al. (2014): Limited tree-ring evidence for a 1540 European 'Megadrought'
}

\author{
Ulf Büntgen ${ }^{1,2,3} \cdot$ Willy Tegel $^{4} \cdot$ Marco Carrer $^{5}$. \\ Paul J. Krusic ${ }^{6,7} \cdot$ Michael Hayes ${ }^{8,3}$ • Jan Esper ${ }^{9}$
}

Received: 12 August 2014 / Accepted: 16 November 2014 / Published online: 9 May 2015

(C) Springer Science+Business Media Dordrecht 2015

\begin{abstract}
Wetter et al. (2014; hereinafter W14) conclude that western Europe experienced significantly higher temperatures in AD 1540 compared to all other years in the instrumental record, including the summer heat waves of 2003 and 2010 (Schär et al. 2004; Barriopedro et al. 2011). Based on 300+ first-hand documentary weather reports, the authors argue that large parts of Europe were hit by an unprecedented, 11-month-long, 'Megadrought' in 1540 exceeding all recorded and reconstructed levels, and falling outside the probability range of state-of-the-art palaeoclimate model simulations. Despite compiling, transforming and interpreting an exceptional pool of documentary evidence, W14 neglected to systematically analyse the existing collection of European tree ring-based climate reconstructions. An independent comparison of their findings from societal entries against natural proxy archives, however, would have been beneficial. For example, Pauling et al. (2006), already identified low precipitation amounts in 1540 derived mainly from tree-ring analyses, a study not cited in W14. In this reply we look into some of the tree-ring data available back to 1540 and before, and demonstrate that W14's conclusion regarding the inability of natural proxy archives to record climate extremes is not defensible.
\end{abstract}

This comment refers to the article available at: http://dx.doi.org/10.1007/s10584-014-1184-2.

Ulf Büntgen

buentgen@wsl.ch

1 Swiss Federal Research Institute WSL, Birmensdorf, Switzerland

2 Oeschger Centre for Climate Change Research, Bern, Switzerland

3 Global Change Research Centre AS CR, Brno, Czech Republic

4 Institute for Forest Growth IWW, University of Freiburg, Freiburg, Germany

5 Dipartimento TeSAF, Agripolis, University of Padova, Legnaro, Italy

6 Navarino Environmental Observatory, Messinia, Greece

7 Department of Physical Geography, Stockholm University, Stockholm, Sweden

8 National Drought Mitigation Center, University of Nebraska-Lincoln, Lincoln, NE, USA

9 Department of Geography, Johannes Gutenberg University, Mainz, Germany 
Socio-economic responses to climatic extremes have caught the attention of archaeologists, climatologists and historians. This intriguing relationship mainly results from devastating temperature and/or hydroclimatic affects on the balance between climate and natural or agricultural resources essential to the wellbeing of ancient societies (McCormick et al. 2012). Coincident economic, political and societal consequences to rapid climate shifts, ranging from inter-annual extremes to century-long trends, have been reported in various biogeographic zones on almost all continents (Hsiang et al. 2013).

Based on documentary entries from the 16th century, describing the climate in 1540, W14 postulate there is an inconsistent growth response in trees from different locations across the Alpine arc and surrounding lowland sites. We maintain, these few and selective examples of heterogeneous ring width and maximum latewood variations are not sufficient for drawing quantitatively meaningful conclusions on a European-wide 'Megadrought' in 1540. W14 hypothesize subalpine larch (Larix decidua) and other montane deciduous tree species lost significant amounts of needles and leaves in 1540. Without supporting plant physiological and/ or statistical corroboration this assumption is contestable. Such a response (the loss of significant amounts of foliage) could not go unnoticed by dendrochronologists working in the region, mainly those producing extended chronologies from alpine and lowland forest species. Nevertheless, yet rather decisively, W14 advise caution when utilizing natural proxy records, particularly tree ring-based reconstructions of climatic extremes, because the information from such archives needs, whenever possible, be double-checked against societal records that provide the "most accurate detail".

While we agree with the concept of multi-proxy cross comparison and validation, even incorporating model output, we do not agree, together with others (Jones et al. 2009), with the subjective classification of better societal versus weaker natural proxy archives. In contrast to providing convincing documentary evidence for an outstanding drought in 1540, as already introduced in Wetter and Pfister (2013), W14 missed the opportunity to test their hypotheses against the massively replicated, millennial-long tree-ring chronologies available from several species and regions in Europe (Tegel et al. 2010).

Here, we use a total of 24'303 individual tree-ring width measurement series from living, historical, archaeological and subfossil wood, continuously covering the last 1000 years. This compilation represents nine annually resolved and geographically distributed fir, oak, larch and pine datasets from low-elevation sites across central Europe and high-elevation sites in the Alps, Pyrenees and Balkans (Table 1). After power-transformation, age-trend removal (using 20-year cubic smoothing splines), chronology development (by bi-weight robust means) and variance stabilization (ratios of the normalized chronologies from moving 31-year standard deviation values), all nine chronologies are optimized to reflect year-to-year variability (see Battipaglia et al. 2010 and Büntgen et al. 2011a for methodological details). This well replicated and absolutely dated collection of chronologies is ideal for describing both site and species-specific climate responses in 1540 and surrounding years, and places the growth pattern of that year in a millennium-long context.

An individual fir sample from northeastern France (fir being one of the most droughtsensitive European conifer species) shows normal growth rates before, during and after 1540, without any indication of drought stress or sign of other disturbances in the early to mid-16th century (Fig. 1). More convincing evidence, compared to this specific example from a single historical tree core, can be found in a central European collection of 1'733 fir samples that exhibit normal growth in 1540 followed by a smaller ring 1 year later (Fig. 1a). A central European oak chronology containing a total of 466 samples shows similar, though less intense, growth 
Table. 1 Characteristics of the nine tree-ring width chronologies, with emphasis on their specific replication (Series) and average growth rate (AGR) in AD 1540 (grey shadow). 'Signal' refers to the published climate sensitivity and 'MSL' describes the mean segment length of the trees included in a dataset

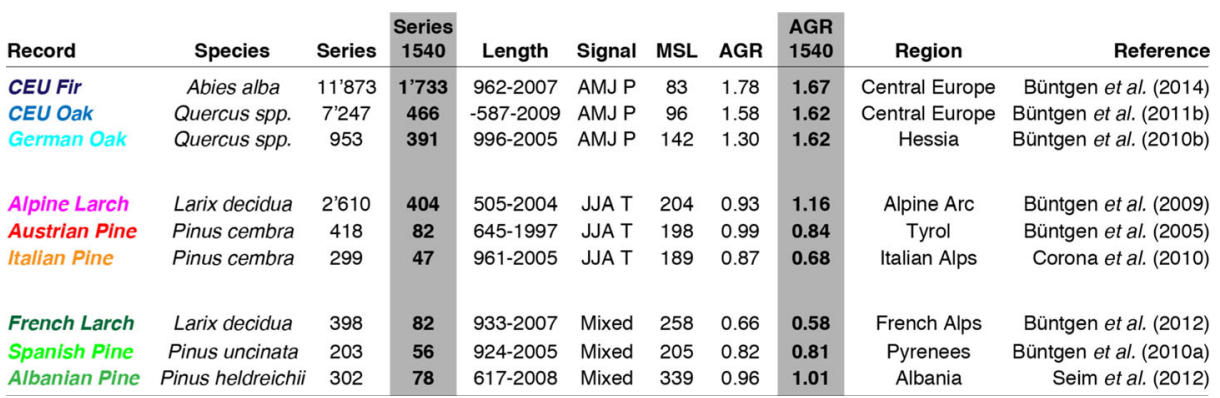

variations in 1540. In 391 oaks from Germany the years 1540 and 1541 are characterized by positive ring width anomalies. None of these three precipitation-sensitive tree-ring chronologies (i.e. data that represent sites and species for which annual growth rates are predominantly controlled by changes in precipitation totals at or near the beginning of the vegetation period) provide any indication of unusual drought conditions at the transition from spring to summer in 1540. This finding is not only valid for the short 1530-1550 interval but also with respect to the last millennium, during which many other years revealed larger growth deviations.

The three high-elevation, temperature-sensitive chronologies from the Alpine arc display positive growth in 1539 and 1540, followed by a sharp decline to 1542 (Fig. 1b). This pattern, based on 533 conifer samples, is indicative of above average summer temperatures in 1539 and 1540, though the deviation is not exceptional at the millennial-scale. Our findings are in line with Battipaglia et al. (2010), who used three 1000-year-long chronologies of maximum latewood density from the Alpine arc and found 1540 to be the 26st warmest April-September season between AD 1000 and 2005. A new reconstruction of central European summer drought that uses annually resolved variations in the carbon isotopes $\left(\delta^{13} \mathrm{C}\right)$ of living and historical larch wood (Kress et al. 2014) shows a less clear pattern, with the summer warmth of 1540 (July-August) ranking 495th between AD 800 and 2004. Similarly, a collection of 216 conifer samples from high-elevation sites in the Spanish Pyrenees, French Alps and Albanian Balkans indicates heterogeneous growth variations in 1540 (Fig. 1c). Above average ring width is recorded in Spain and France from 1538 to 1542, but an abrupt growth depression in 1540 is found in Albania. Although these three Mediterranean records are characterized by weak relationships between increment growth and climatic forcing (Büntgen et al. 2010a, 2012; Seim et al. 2012), appearing less suitable for studying the 'Megadrought' in 1540, their consideration still seems advisable as the data reveal no sign of needle or leaf loss. Admittedly, we still have lots to learn about ring formation in more southern environments, where climateinduced seasonality is often less distinct.

A closer look at the frequency distributions of the nine European tree-ring chronologies finds 1540 to be most peculiar in the Austrian pine data where it is the fifth most positive value out of 1002 growth rings (Fig. 2). However, 1540 only ranks 107 and 135 in the two other high-elevation larch and pine chronologies from across the Alpine arc and parts of the Italy Alps, respectively (Fig. 2b). In the low-elevation datasets, tree growth in 1540 is not near the distribution tails, but rather close to the centre on the negative (twice) and once on the positive side of the histograms, indicating "normal" growing conditions were widespread in central 


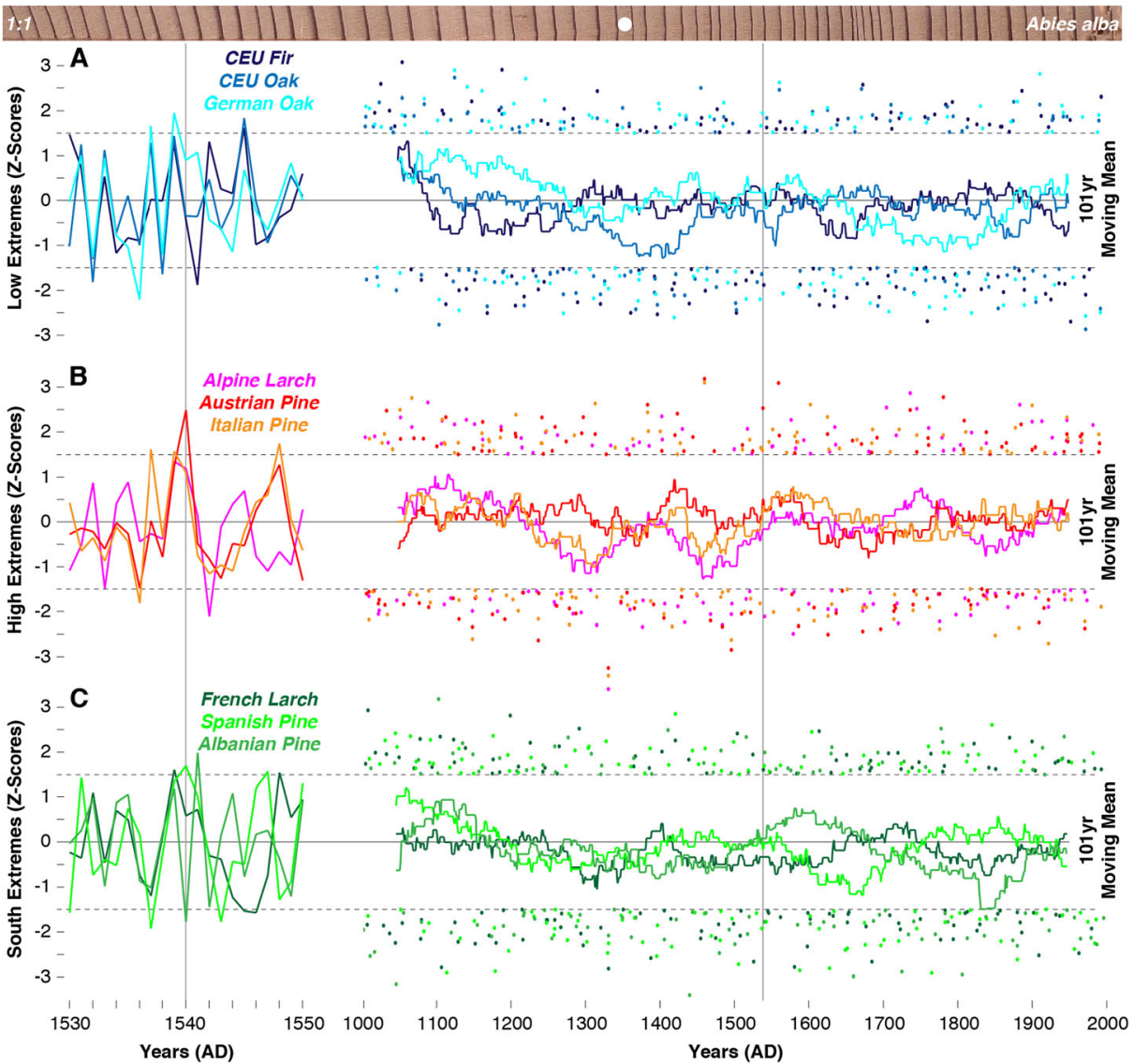

Fig. 1 Core sample of a fir (Abies alba) roof timber from a farmhouse in the village of Bult (dating to AD 1603), northeastern France, which reveals unexceptional TRW anomalies before, during and after 1540 (white dot). Temporal distribution of TRW deviations exceeding 1.5 standard deviations (dots) of nine chronologies, sorted by (a) precipitation sensitive, low-elevation sites in central Europe, (b) temperature sensitive, high-elevation sites the Alps, and (c) mixed-signal, higher elevation sites in the southern French Alps, Pyrenees and Balkans. Curves in the center are 100-year moving averages. Diagrams on the left side show the site-specific TRW variability between 1530 and 1550. Grey vertical lines indicate 1540

Europe (Fig. 2a). The most inconsistent pattern originates from the three southern sites with mixed climate sensitivities (Fig. 2c), adding only limited insight on the hydroclimatic conditions in 1540. Nevertheless, none of the Mediterranean chronologies implies an unprecedented 11-month-long 'Megadrought' nor a record-breaking heat wave as described in W14.

In summary, the presumed 1540 'Megadrought' and its associated heat wave, did not leave a conspicuous fingerprint in the tree rings of hundreds of conifers from higher elevation settings in the European Alps, Pyrenees and Balkans, nor in thousands of angiosperms from lower elevation sites in Austria, France, Germany, Switzerland and the Czech Republic, as would be expected by the degree of prolonged drought stress hypothesized in W14. Hence, the credibility of historical accounts reporting widespread needle and leaf losses as a response to drought, and the conclusion regarding a general dysfunction of natural proxy archives, with 

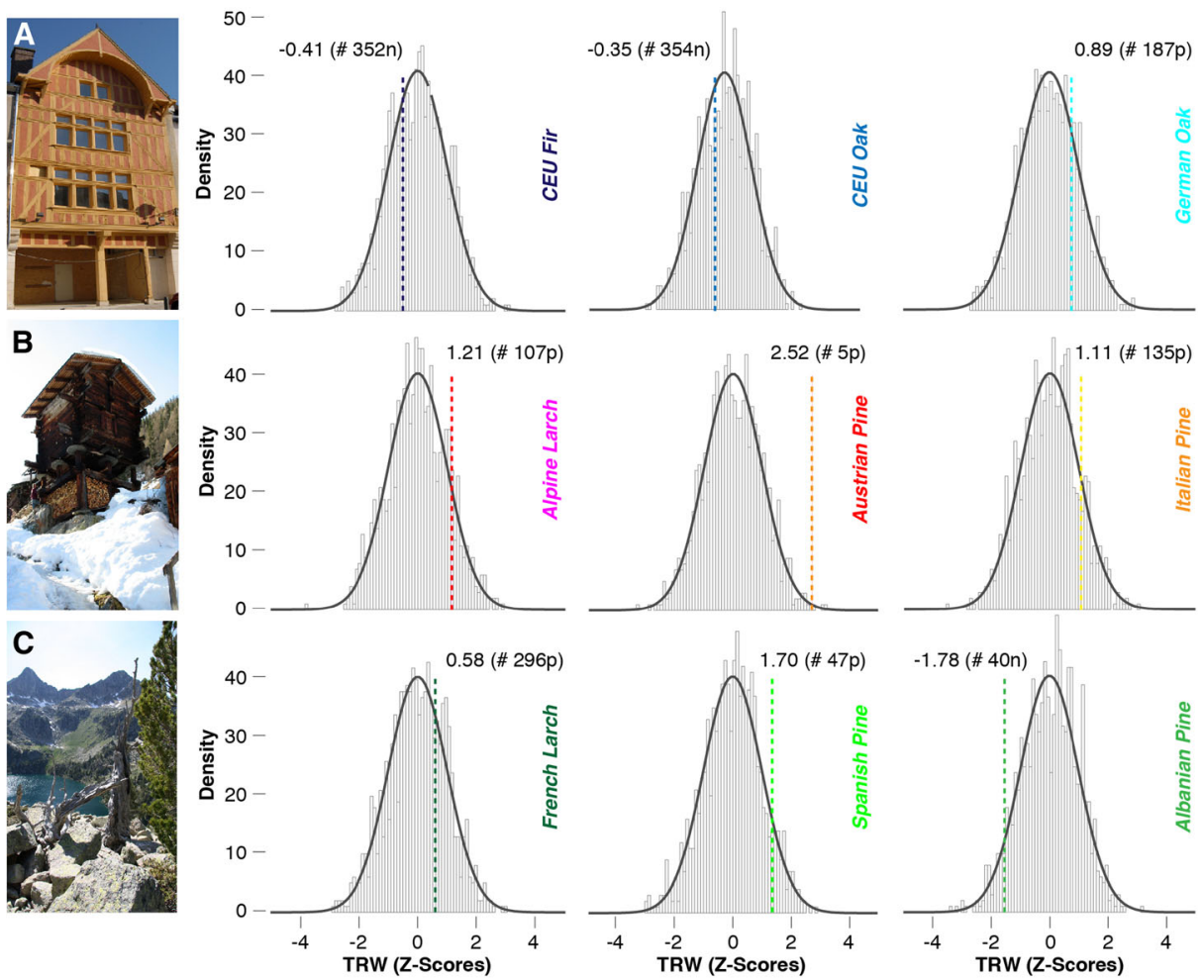

Fig. 2 Examples of dendrochronological material from (a) low-elevation oak timbers in northeastern France (Troyes), (b) high-elevation larch logs in the western Swiss Alps (Lötschental), and (c) dry-dead pine wood in the central Spanish Pyrenees (Gerber). Frequency distribution plots integrate the annual TRW values of the last millennium for each of the nine chronologies. Dotted lines indicate the position of the 1540 value, with the numbers referring to the TRW value and its 1000-year ranking

tree rings in particular, appears unjustified, especially if descriptions predominantly originate from gardens, parks and orchards.

Although deciduous broadleaf species can lose their leaves under severe drought, conifers are usually more tolerant to soil moisture deficit. Severe drought would need to last several years to cause needle loss and crown dieback in conifer species (see Breshears et al. 2005 for an example of drought-induced regional vegetation die-off in the southwestern US). In reaction to a water deficit, trees first start closing their stomata to conserve water (Rennenberg et al. 2006). If drought persists, they may shed their foliage that ultimately results in a dramatic hydraulic failure of the xylem (Bréda et al. 2006). Both these reactions to drought significantly diminish photosynthetic activity and translate into substantially reduced tree-ring widths and altered densities (Choat et al. 2012). Given the so-called biological memory inherent to treering chronologies, resulting from the dependency of annual ring formation on previous year circumstances (Frank et al. 2007), the 1540 'Megadrought' would be clearly visible in one or even several narrow rings following this event. Since these indicators are missing in our European tree-ring network, the suggestion of an unprecedented, near continental-wide and 11-month-long 'Megadrought' in 1540 appears unlikely. 
Using a well replicated, continental-wide and millennium-long pool of tree-ring width chronologies, our results demonstrate that W14 only considered a small fraction of annually resolved proxy evidence available for 1540. In so doing, W14 missed a more complete picture of climate variability during that year, and thus probably overstated the intensity and duration of the 1540 drought event. Undoubtedly, more palaeoclimatic research at the interface of natural and societal archives is needed to provide a better understanding of the causes and consequences of past climatic extremes that have occurred over the last millennium. However, future studies should be particularly cautious to not fuel the ongoing 'climate change debate' without unambiguous proof.

Though the enormous effort spent by W14 is highly appreciated, their conclusions regarding natural proxy archives could jeopardize efforts towards properly reconstructing climate. We believe in the strength of interdisciplinary efforts to improve knowledge on past, present and future interactions between climate variability and human society (Büntgen et al. 2011b), and we are aware of the importance of judiciously linking historical and palaeoclimatological evidence (Pauling et al. 2006; Büntgen et al. 2011a), for which central Europe offers a particularly rich record. However, given the expectation that extreme drought events and heat waves might increase in the near future (Trenberth et al. 2014; Kirtman et al. 2013), we are concerned about hastily translating information on past climatic 'extremes' into a nexus of environmental and societal threats.

Describing his concern related to the challenges posed by future combinations of heat and drought, Overpeck (2013) summarizes our position by advocating that all available proxy records are valuable to comprehend the complex nature of past droughts and assist decision makers in identifying appropriate strategies in preparation of future events. A better understanding of climate-driven extremes, which may range from several months to decades, in the functioning and productivity of different European forest ecosystems is also beneficial for other disciplines (Hegerl et al. 2011). Moreover, long-term changes in the frequency and severity of drought events and heat waves are still poorly understood (Masson-Delmotte et al. 2013). In this regard, the pursuit of a robust, well-verified paleoclimatic insight is important towards improving adaptation and mitigation strategies for predicted climate change (Woodhouse et al. 2010; Milly et al. 2008).

Acknowledgments Edward R. Cook, Director of the LDEO Tree-Ring Laboratory at Columbia University, USA kindly commented on an earlier manuscript version. UB and $\mathrm{MH}$ were supported by the Czech project 'Building up a multidisciplinary scientific team focused on drought' (No. CZ.1.07/2.3.00/20.0248).

\section{References}

Barriopedro D, Fischer EM, Luterbacher J, Trigo RM, García-Herrera R (2011) The hot summer of 2010: redrawing the temperature record map of Europe. Science 332:220-224

Battipaglia G, Frank DC, Büntgen U, Dobrovolny P, Brazdil R, Pfister C, Esper J (2010) Five centuries of Central European temperature extremes reconstructed from tree-ring density and documentary evidence. Glob Planet Chang 72:182-191

Bréda N, Huc R, Granier A, Dreyer E (2006) Temperate forest trees and stands under severe drought: a review of ecophysiological responses, adaptation processes and long-term consequences. Ann For Sci 63:625-644

Breshears DD, Cobb NS, Rich PM, Price KP, Allen CD, Balice RG, Romme WH, Kastens JH, Floyd ML, Belnap J, Anderson JJ, Myers OB, Meyer CW (2005) Regional vegetation die-off in response to globalchange-type drought. Proc Natl Acad Sci U S A 102(42):15144-15148 
Büntgen U, Esper J, Frank DC, Nicolussi K, Schmidhalter M (2005) A 1052-year tree-ring proxy for Alpine summer temperatures. Clim Dyn 25:141-153

Büntgen U, Frank D, Carrer M, Urbinati C, Esper J (2009) Improving alpine summer temperature reconstructions by increasing sample size. In: Kaczka R, Malik I, Owczarek P, Gärtner H, Helle G, Heinrich I (eds) TRACE - Tree Rings in Archaeology, Climatology and Ecology, Vol. 7. GFZ Potsdam, Scientific Technical Report STR 09/03, Potsdam, pp 226

Büntgen U, Frank D, Trouet V, Esper J (2010a) Diverse climate sensitivity of Mediterranean tree-ring width and density. Trees 24:261-273

Büntgen U, Trouet V, Frank D, Leuschner HH, Friedrichs D, Luterbacher J, Esper J (2010b) Tree-ring indicators of German summer drought over the last millennium. Quat Sci Rev 29:1005-1016

Büntgen U, Brázdil R, Heussner KU, Hoffmann J, Kontic R, Kyncl T, Pfister C, Chromá K, Tegel W (2011a) Combined dendro-documentary evidence of central European hydroclimatic springtime extremes over the last millennium. Quat Sci Rev 30:3947-3959

Büntgen U, Tegel W, Nicolussi K, McCormick M, Frank D, Trouet V, Kaplan J, Herzig F, Heussner U, Wanner H, Luterbacher J, Esper J (2011b) 2500 years of European climate variability and human susceptibility. Science 331:578-582

Büntgen U, Frank D, Neuenschwander T, Esper J (2012) Fading temperature sensitivity of Alpine tree growth at its Mediterranean margin and associated effects on large-scale climate reconstructions. Clim Chang 114: 651-666

Büntgen U, Tegel W, Kaplan JO, Schaub M, Hagedorn F, Bürgi M, Brázdil R, Helle G, Carrer M, Heussner KU, Hofmann J, Kontic R, Kyncl T, Kyncl J, Camarero JJ, Tinner W, Esper J, Liebhold A (2014) Placing unprecedented recent fir growth in a European-wide and Holocene-long context. Front Ecol Environ 12: 100-106

Choat B, Jansen S, Brodribb TJ et al (2012) Global convergence in the vulnerability of forests to drought. Nature 491:752-755

Corona C, Guiot J, Edouard JL, Chalié F, Büntgen U, Nola P, Urbinati C (2010) Millennium-long summer temperature variations in the European Alps as reconstructed from tree rings. Clim Past 6:379-400

Frank DC, Büntgen U, Böhm R, Maugeri M, Esper J (2007) Warmer early instrumental measurements versus colder reconstructed temperatures: Shooting at a moving target. Quat Sci Rev 26:3298-3310

Hegerl G, Hanlon H, Beierkuhnlein C (2011) Elusive extremes. Nat Geol Sci 4:142-143

Hsiang SM, Burke M, Miguel E (2013) Quantifying the influence of climate on human conflict. Science 341: 1235367

Jones PD, Briffa KR, Osborn TJ et al (2009) High-resolution palaeoclimatology of the last millennium: a review of current status and future prospects. The Holocene 19(1):3-49

Kirtman B, Power SB, Adedoyin JA et al (2013) Near-term climate change: Projections and predictability. In: Stocker TF, Qin D, Plattner G-K et al (eds) Climate change 2013: the physical science basis. Contribution of Working Group I to the Fifth Assessment Report of the Intergovernmental Panel on Climate Change. Cambridge University Press, Cambridge

Kress A, Hangartner S, Bugmann H, Büntgen U, Frank DC, Leuenberger M, Siegwolf RTW, Saurer M (2014) Swiss tree-rings reveal warm and wet summers during medieval times. Geophys Res Lett. doi:10.1002/ 2013GL059081

Masson-Delmotte V, Schulz M, Abe-Ouchi A et al (2013) Information from Paleoclimate Archives. In: Stocker TF, Qin D, Plattner G-K et al (eds) Climate Change 2013: The Physical Science Basis. Contribution of Working Group I to the Fifth Assessment Report of the Intergovernmental Panel on Climate Change. Cambridge University Press, Cambridge

McCormick M, Büntgen U, Cane MA, Cook ER, Harper K, Huybers P, Litt T, Manning SW, Mayewski PA, More AFM, Nicolussi K, Tegel T (2012) Climate change during and after the Roman Empire: reconstructing the past from scientific and historical evidence. J Interdiscip Hist 43(2):169-220

Milly PCD, Betancourt J, Falkenmark M, Hirsch RM, Kundzewicz ZW, Lettenmaier DP, Stouffer RJ (2008) Stationarity is dead: wither water management. Science 319:573-574

Overpeck JT (2013) The challenge of hot drought. Nature 503:350-351

Pauling A, Luterbacher J, Casty C, Wanner H (2006) Five hundred years of gridded high-resolution precipitation reconstructions over Europe and the connection to large-scale circulation. Clim Dyn 26:387-405

Rennenberg H, Loreto F, Polle A, Brilli F, Fares S, Beniwal R, Gessler A (2006) Physiological responses of forest trees to heat and drought. Plant Biol 8:556-571

Schär C, Vidale PL, Lüthi D, Frei C, Häberli C, Liniger MA, Appenzeller C (2004) The role of increasing temperature variability in European summer heatwaves. Nature 427:332-336

Seim A, Büntgen U, Fonti P, Haska H, Herzig F, Tegel W, Trouet V, Treydte K (2012) The paleoclimatic potential of a millennium-long tree-ring width chronology from Albania. Clim Res 51:217-228 
Tegel W, Vanmoerkerke J, Büntgen U (2010) Updating historical tree-ring records for climate reconstruction. Quat Sci Rev 29:1957-1959

Trenberth KE, Dai A, van der Schrier G, Jones PD, Barichivich J, Briffa KR, Sheffield J (2014) Global warming and changes in drought. Nat Clim Chang 4:17-22

Wetter O, Pfister C (2013) An underestimated record breaking event - why summer 1540 was likely warmer than 2003. Clim Past 9:41-56

Wetter O, Pfister C, Werner JP et al (2014) The year-long unprecedented European heat and drought of 1540 — a worst case. Clim Chang 125:349-363

Woodhouse CA, Meko DM, MacDonald GM, Stahle DW, Cook ER (2010) A 1,200-year perspective of 21st century drought in southwestern North America. Proc Natl Acad Sci U S A 107(50):21283-21288 